\title{
PENGARUH KEPEMIMPINAN TRANSFORMASIONAL DAN EMPLOYEE ENGAGEMENT TERHADAP KINERJA KARYAWAN PT. TASPEN (PERSERO) KANTOR CABANG UTAMA SURABAYA
}

\author{
Pramita Trisnaning Cahyandani \\ Universitas Negeri Surabaya \\ pramitacahyandani@mhs.unesa.ac.id
}

\begin{abstract}
This study aimed to examine and analyze transformational leadership and employee engagement on employee performance at PT. Taspen (Persero) Kantor Cabang Utama Surabaya. Quantitative methods use to process questionnaire that employees have filled in. The study population was all employees of PT. Taspen (Persero) Kantor Cabang Utama Surabaya consisting of 63 employees. The analytical tool used is multiple linear regression analysis by IBM SPSS 23 software. This study indicates that transformational leadership has a positive impact on employee performance. Employee engagement has a positive impact on employee performance. Transformational leadership and employee engagement can affect the performance of employees of PT. Taspen (Persero) Kantor Cabang Utama Surabaya.
\end{abstract}

Keywords: employee engagement; employee performance; transformational leadership.

\section{PENDAHULUAN}

Sumber daya manusia adalah harta atau aset paling berharga dan paling penting dimiliki oleh suatu organisasi/perusahaan, karena keberhasilan organisasi sangat ditentukan oleh unsur manusia. Jika organisasi/perusahaan ingin mencapai kinerja yang maksimal maka diperlukannya sumber daya manusia yang berkualitas dalam melakukan operasional perusahaan (Ardana dalam Mahendra \& Mujiati, 2015).

Setiap perusahaan perlu senantiasa meningkatkan kinerja karyawannya secara terus-menerus dan berkelanjutan karena setiap karyawan tersebut berperan penting dalam setiap perencanaan, pengorganisasian, pelaksanaan dan pengendalian berbagai strategi lintas fungsional dalam upaya untuk mencapai visi, misi dan tujuan yang telah ditetapkan. Perusahaan dapat menggunakan berbagai variabel yang signifikan untuk meningkatkan kinerja karyawannya (Sugiono \& Rachmawati, 2019).

Menurut Sulastri (2017), kinerja merupakan perwujudan kerja yang dilakukan oleh karyawan yang biasanya dipakai sebagai dasar penilaian terhadap karyawan atau organisasi, sehingga perlu diupayakan untuk meningkatkan kinerja. Sedangkan Purba \& Gunawan (2018), kinerja merupakan deskripsi sejauh mana keberhasilan ataupun kegagalan organisasi dalam melakukan operasinya untuk menggapai sasaran, tujuan, visi, serta misi organisasi. Tidak hanya itu, kinerja pula berarti mutu serta kuantitas kerja ataupun kelompok orang untuk menggapai tujuan tertentu.

Perusahaan dapat menggunakan berbagai variabel yang signifikan untuk meningkatkan kinerja karyawannya. Salah satunya adalah variabel kepemimpinan transformasional (Sugiono \& Rachmawati, 2019). Gaya kepemimpinan yang baik dan tepat akan menimbulkan sebuah motivasi kerja yang juga baik bagi para karyawannya. Sukses atau tidaknya karyawan dalam prestasi kerja juga dapat dipengaruhi oleh gaya kepemimpinan atasannya. Hubungan yang positif antara pemimpin dan bawahannya akan mendukung semua aspek didalamnya termasuk kinerja para karyawannya yang tentu saja akan memiliki dampak yang baik juga terhadap kinerja perusahaan secara menyeluruh (Candra dalam Giovanni, 2018).

Istilah transformasional berinduk dari kata to transform, yang bermakna mentransformasikan atau mengubah sesuatu menjadi bentuk lain yang berbeda. Transformasional bermakna sifat-sifat yang dapat mengubah sesuatu menjadi bentuk lain, misalnya mengubah energi potensial menjadi energi aktual atau motif berprestasi menjadi prestasi riil (Indarti dalam Bakhtiar, 2019). Kepemimpinan 
Pramita Trisnaning Cahyandani. Pengaruh Kepemimpinan Transformasional dan Employee Engagement terhadap Kinerja Karyawan PT Taspen (Persero) Kantor Cabang Utama Surabaya

transformasional menciptakan visi, lingkungan dan memberikan motivasi kepada bawahan untuk berprestasi. Implikasinya bawahan akan merasa kagum, percaya, berkomitmen dan merasa terikat dengan organisasi. Hal inilah yang menunjukkan kepemimpinan transformasional memberikan dampak positif pada kinerja bawahan dan engagement karyawan. Karyawan yang merasa terikat atau engaged akan mampu memberikan keseluruhan dirinya dalam usaha pencapaian tujuan, visi dan misi perusahaan (Kahn dalam Giovanni, 2018).

Menurut Bedarkar \& Pandita (2014), employee engagement adalah masalah kepedulian terhadap pemimpin dan manajer dalam organisasi di seluruh dunia, karena diakui sebagai elemen vital dalam menentukan tingkat efektifitas, inovasi, dan daya saing organisasi. Karyawan dengan tingkat engagement yang tinggi mendatangkan keunggulan kompetitif bagi perusahaan, kinerja yang tinggi serta rendah turn over (Giovanni, 2018). Tujuan penelitian ini adalah untuk mengetahui pengaruh kepemimpinan transformasional dan employee engagement terhadap kinerja karyawan PT. Taspen (Persero) Kantor Cabang Utama Surabaya.

\section{KAJIAN PUSTAKA DAN PENGEMBANGAN HIPOTESIS}

\section{Kepemimpinan Transformasional}

Bai et al. (2016) menjelaskan bahwa kepemimpinan transformasional digunakan para pemimpin untuk menginspirasi karyawannya melalui visi dengan rasa penerimaan untuk memperluas dan meningkatkan kepentingan karyawan mereka dengan menumbuhkan kesadaran dan penerimaan kepentingan kolektif dan kepentingan bagi diri karyawan sendiri.

Menurut Jun (2017), kepemimpinan transformasional mulai muncul sebagai cara mengatasi suatu keterbatasan, dan penelitian teoritis serta empiris telah diperluas dengan fenomena yang terjadi. Kepemimpinan transformasional juga bisa efektif dalam mencapai kinerja organisasi yang lebih besar dengan mendorong anggota untuk mencapai tujuan bersama. Pemberdayaan organisasi mendapatkan dampak yang positif karena kepemimpinan transformasional dan meningkatkan sikap anggota yang berorientasi tugas dan kinerja organisasi.

\section{Employee Engagement}

Bedarkar \& Pandita (2014), menjelaskan employee engagement merupakan masalah kepedulian terhadap pemimpin dan manajer dalam organisasi di seluruh dunia, karena diakui sebagai elemen vital dalam menentukan tingkat efektifitas, inovasi, dan daya saing organisasi.

Menurut Putri \& Soedarsono (2017), rasa engaged yang dimiliki karyawan memiliki dampak yang efektif karena rasa energetic yang dimilikinya dalam mengerjakan tuntutan pekerjaan mereka dan merasa mampu untuk menyelesaikannya. Keterlibatan ini mempunyai hubungan dengan pekerjaan serta memiliki dampak yang positif dan dibedakan menjadi tiga, yaitu: vigor, absorption, vigor, dan dedication.

\section{Kinerja Karyawan}

Menurut Sulastri (2017), kinerja merupakan perwujudan kerja yang dilakukan oleh karyawan yang biasanya dipakai sebagai dasar penilaian terhadap karyawan atau organisasi, sehingga perlu diupayakan untuk meningkatkan kinerja. Sedangkan Purba \& Gunawan (2018), kinerja merupakan deskripsi sejauh mana keberhasilan ataupun kegagalan organisasi dalam melakukan operasinya untuk menggapai sasaran, tujuan, tujuan, visi, serta misi organisasi. Tidak hanya itu, kinerja pula berarti mutu serta kuantitas kerja ataupun kelompok orang untuk menggapai tujuan tertentu.

Menurut Sattar et al. (2015), struktur strategi sumber daya manusia adalah alat yang luar biasa yang dapat berperan penting dalam meningkatkan berbagai praktek sumber daya manusia. Struktur gaji yang tidak memadai, kurangnya peluang, skema insentif yang lemah untuk kinerja pekerjaan yang sangat baik, kode promosi berdasarkan senioritas daripada kinerja aktual, perlakuan hukuman, keterlambatan promosi, tidak adanya modul kompensasi, dan strategi motivasi adalah penentu utama keterlibatan dan kinerja seorang karyawan di perusahaannya. 


\section{Hubungan antar Variabel}

Kepemimpinan transformasional merupakan kepemimpinan yang menanamkan intelektual anggota, memberikan dukungan moral, dan fokus terhadap visi perusahaan. Subhi \& Yuniati (2014) menjelaskan bahwa demi meraih suatu tujuan yang dinginkan diperlukan suatu kondisi untuk merangsang anggotanya merupakan sebuah tanggungjawab menjadi pemimpin. Hayward (2005) mengemukakan bahwa kinerja karyawan berhubungan secara signifikan dengan gaya kepemimpinan transformasional.

H1: Diduga ada pengaruh kepemimpinan transformasional terhadap kinerja karyawan.

Bedarkar \& Pandita (2014) mengemukakan bahwa perhatian yang signifikan telah diberikan pada keterlibatan karyawan dengan hasil keuangan organisasi. Pengamatan yang dilakukan oleh beberapa penelitian menghasilkan bahwa kinerja organisasi dapat meningkat disaat kinerja seorang karyawan lebih besar, sehingga keterlibatan karyawan memiliki dampak dengan meningkatnya sebuah kinerja di dalam organisasi. Dengan demikian, organisasi lebih baik memenuhi apa yang diharapkan oleh karyawan sehingga dapat bekerja secara aktif yang kemudian akan terciptanya dampak kepada kinerja karyawannya dan akan memiliki pengaruh terhadap kinerja organisasinya.

H2: Diduga ada pengaruh employee engagement terhadap kinerja karyawan.

Kepemimpinan transformasional lebih mementingkan perusahaan ketimbang mementingkan hal pribadinya, sehingga setiap karyawan memiliki peningkatan didalam perasaannya guna membantu perusahaan. Dalam penelitian Putri \& Soedarsono (2017) menjelaskan bahwa terkait kepemimpinan transformasional dan employee engagement tinggi, hal ini menggambarkan bahwa apabila kedua variabel digabung menghasilkan hasil yang tinggi yang sejalan dengan pengolahan data deskriptif untuk kinerja yang menghasilkan nilai tinggi juga.

H3: Diduga ada pengaruh kepemimpinan transformasional dan employee engagement terhadap kinerja karyawan.

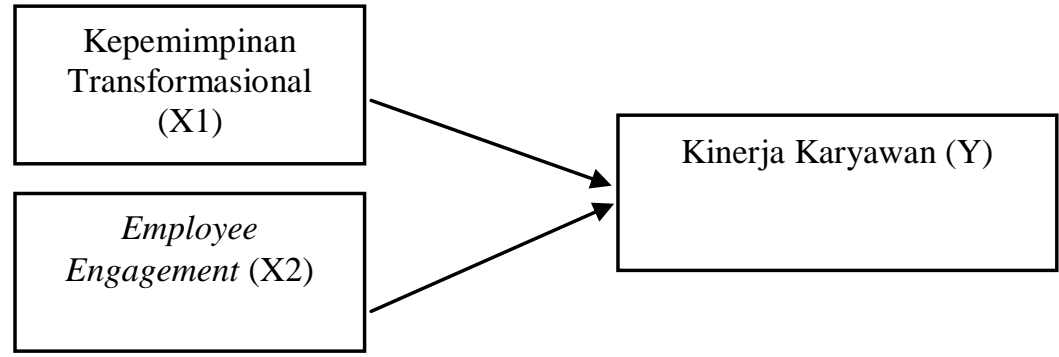

Gambar 1. KERANGKA KONSEPTUAL

\section{METODE PENELITIAN}

Penelitian ini merupakan penelitian kuantitatif. Dalam penelitian ini data bersumber dari data primer dengan memakai teknik pengumpulan secara wawancara, kuesioner, dan observasi. Pada PT. Taspen (Persero) Kantor Cabang Utama Surabaya penelitian ini dilakukan dengan memakai teknik pengambilan sampel jenuh secara keseluruhan sebanyak 63 karyawan. Kemudian data diolah menggunakan spss dengan uji regresi linier berganda.

\section{HASIL DAN PEMBAHASAN}

\section{Uji Regresi Linier Berganda}

Berdasarkan output hasil regresi linier berganda di atas maka dapat diperoleh persamaan regresi (1).

$\mathrm{Y}=6,033+0,137 \mathrm{X} 1+0,681 \mathrm{X} 2+\mathrm{e}$ 
Pramita Trisnaning Cahyandani. Pengaruh Kepemimpinan Transformasional dan Employee Engagement terhadap Kinerja Karyawan PT Taspen (Persero) Kantor Cabang Utama Surabaya

Tabel 1.

HASIL REGRESI LINIER BERGANDA

\begin{tabular}{llccccc}
\hline \multicolumn{1}{c}{ Model } & \multicolumn{2}{c}{ Unstandardized Coefficients } & Standardized Coefficients & & \\
B & Std. Error & & Beta & Sig. \\
\hline 1 & (Constant) & 6.033 & 3.126 & & 1.930 & .058 \\
Kepemimpinan & .137 & .062 & .200 & 2.192 & .032 \\
& Transformasional & .137 & .076 & 7.404 & .000 \\
\hline Employee Engagement & .681 & .092 & & .676
\end{tabular}

Sumber: Output SPSS

Nilai konstanta dari persamaan di atas sejumlah 6,033 sehingga dapat dijelaskan bahwa kedua variabel dikatakan tidak mempunyai penambahan dan konstan, maka sejumlah 6,033 merupakan nilai variabel kinerja karyawan. Diperoleh nilai koefisien regresi sejumlah 0,137 pada variabel kepemimpinan transformasional yang mempunyai arti disaat variabel independen tetap namun adanya kenaikan pada variabel kepemimpinan transformasional, maka sejumlah 0,137 merupakan nilai kenaikan pada variabel kinerja karyawan. Nilai koefisien regresi sejumlah 0,681 yang positif pada variabel employee engagement mempunyai arti disaat variabel independen lainnya tetap namun terjadinya kenaikan pada variabel employee engagement, maka akan adanya kenaikan sejumlah 0,681 dialami oleh variabel kinerja karyawan.

Melalui hasil regresi linier berganda pada tabel 1, dengan hasil pada pengujian hipotesis dalam penelitian ini menghasilkan uji t antara variabel dependen dengan independen. Tingkat signifikansin sejumlah $0,032 \quad(<0,05)$ dan sejumlah 2,192 yang merupakan nilai $t$ hitung dari variabel kepemimpinan transformasional. Hal tersebut mempunyai arti bahwa Ha diterima, sehingga kinerja karyawan mempunyai pengaruh signifikan dengan kepemimpinan transformasional. Dalam penelitian ini pengujian hipotesis menghasilkan uji t variabel employee engagement sejumlah 7,404 dalam $\mathrm{t}$ hitungnya dan nilai sejumlah $0,000(<0,05)$ sebagai tingkat signifikansinya. Sehingga Ha diterima, sehingga dapat dikatakan bahwa kinerja karyawan mempunyai pengaruh signifikan dengan employee engagement.

\section{Uji Signifikansi Simultan (Uji F)}

Uji statistik F pada dasarnya menunjukkan apakah semua variabel independen yang dimasukkan dalam model mempunyai pengaruh secara bersama-sama terhadap variabel dependen. Apabila tingkat probabilitasnya lebih rendah dari 0,05 maka dapat disimpulkan bahwa semua variabel independen secara bersama-sama berpengaruh terhadap variabel dependen (Ghozali, 2013:98).

Tabel 2.

\section{HASIL UJI F}

\begin{tabular}{|c|c|c|c|c|c|}
\hline Model & Sum of Squares & Df & Mean Square & $\mathbf{F}$ & Sig. \\
\hline 1 Regression & 853.594 & 2 & 426.797 & 52.927 & $.000^{\mathrm{b}}$ \\
\hline Residual & 483.834 & 60 & 8.064 & & \\
\hline Total & 1337.429 & 62 & & & \\
\hline
\end{tabular}

Sumber: Output SPSS

Nilai signifikansi pada tabel 2 menghasilkan uji $\mathrm{F}$ kurang dari 0,05 dengan jumlah 0,000 , hal ini berarti bahwa employee engagement mempunyai pengaruh secara simultan dengan variabel kepemimpinan transformasional terhadap kinerja karyawan yaitu variabel dependen.

\section{Koefisien Determinasi $\left(\mathbf{R}^{2}\right)$}

Koefisien determinasi $\left(\mathrm{R}^{2}\right)$ pada intinya digunakan untuk mengukur seberapa jauh kemampuan model dalam menerangkan variasi variabel dependen (Ghozali, 2013:97). Nilai koefisien determinasi adalah nol dan satu. 


\section{Tabel 3. \\ HASIL UJI KOEFISIEN DETERMINASI $\left(\mathbf{R}^{2}\right)$}

\begin{tabular}{lllll}
\hline Model & R & R Square & Adjusted R Square & Std. Error of the Estimate \\
\hline 1 & $.799^{\mathrm{a}}$ & .638 & .626 & 2.83970 \\
\hline
\end{tabular}

Sumber: Output SPSS

Berdasarkan hasil pada tabel di atas dapat dilihat bahwa nilai adjusted $\mathrm{R}^{2}$ pada model regresi sebesar 0,626 . Hal ini menandakan bahwa variasi variabel kepemimpinan transformasional dan employee engagement dapat menjelaskan $62,6 \%$ variasi variabel kinerja karyawan. Sedangkan sisanya, sebesar $37,4 \%$ dijelaskan oleh variabel lain di luar penelitian ini.

\section{Pengaruh Kepemimpinan Transformasional terhadap Kinerja Karyawan pada PT. Taspen (Persero) Kantor Cabang Utama Surabaya}

Hasil analisis statistik menjelaskan adanya pengaruh signifikan positif antara variabel kepemimpinan transformasional terhadap kinerja karyawan. Variabel kepemimpinan transformasional memiliki koefisien bernilai positif yang berarti jika variabel kinerja karyawan mengalami kenaikan, hal tersebut disebabkan oleh variabel kepemimpinan transformasional yang juga naik.

Hal tersebut didukung dari hasil wawancara salah satu karyawan yang menjelaskan bahwa di dalam pekerjaan setiap karyawannya, pemimpin selalu memberikan semangat dan support untuk menyelesaikan setiap pekerjaan dengan sebaik mungkin dan selalu diberi motivasi untuk dapat berhasil juga dalam setiap pekerjaannya.

Hasil penelitian ini didukung oleh penelitian dari Nguyen et al. (2016), Deinert et al. (2015), Yildiz et al. (2014), Semuel et al. (2017), Subhi \& Yuniati (2014), Prastyo (2014), Putri \& Iskandar (2016). Menurut Jun (2017) kepemimpinan transformasional mulai muncul sebagai cara mengatasi suatu keterbatasan, dan penelitian teoritis serta empiris telah diperluas dengan fenomena yang terjadi. Kepemimpinan seperti itu membantu memotivasi anggota organisasi untuk mencapai hasil di luar kepentingan pribadi dan mengakui nilai pekerjaan mereka. Kepemimpinan transformasional juga bisa efektif dalam mencapai kinerja organisasi yang lebih besar dengan mendorong anggota untuk mencapai tujuan bersama. Dampak yang positif dihasilkan oleh kepemimpinan transformasional yaitu pada pemberdayaan organisasi dan meningkatkan sikap anggota yang berorientasi tugas dan kinerja organisasi.

\section{Pengaruh Employee Engagement terhadap Kinerja Karyawan pada PT. Taspen (Persero) Kantor Cabang Utama Surabaya}

Hasil analisis statistik menjelaskan adanya pengaruh yang signifikan positif terhadap kinerja karyawan. Nilai positif koefisien dimiliki oleh variabel employee engagement yang berarti jika disaat kinerja karyawan mengalami suatu kenaikan, hal tersebut disebabkan oleh naiknya variabel employee engagement. Hal tersebut didukung dari hasil wawancara salah satu karyawan yang mana setiap karyawan yang bekerja selalu tampak antusias dan bekerja dengan sungguh-sungguh, sehingga setiap karyawannya cenderung bekerja lebih baik dan memberikan hasil kerja yang baik pula untuk perusahaan.

Hasil penelitian ini didukung oleh penelitian dari Bedarkar \& Pandita (2014), Ramadhan \& Sembiring (2014), Bakti (2016), Handoyo \& Setiawan (2017) sejalan dengan penelitian ini yang mengemukakan bahwa adanya pengaruh yang signifikan positif antara kinerja karyawan dengan employee engagement. Menurut Hanaysha (2016) employee engagement di dalam perilaku organisasi menjadi suatu konsep yang penting dan telah menerima perhatian yang signifikan dalam suatu penelitian akademik. Employee engagement adalah masalah kepedulian terhadap pemimpin dan manajer dalam organisasi diseluruh dunia, karena diakui sebagai elemen vital dalam menentukan tingkat efektifitas, inovasi, dan daya saing organisasi. Menurut Bakti (2016) dalam beberapa tahun terakhir, daya tarik dari perilaku sebuah organisasi merupakan gagasan dari employee engagement. Kinerja perusahaan 
Pramita Trisnaning Cahyandani. Pengaruh Kepemimpinan Transformasional dan Employee Engagement terhadap Kinerja Karyawan PT Taspen (Persero) Kantor Cabang Utama Surabaya

secara keseluruhan memiliki pengaruh dengan employee engagement sehingga daya tarik tersebut muncul.

\section{Pengaruh Kepemimpinan Transformasional dan Employee Engagement terhadap Kinerja Karyawan pada PT. Taspen (Persero) Kantor Cabang Utama Surabaya}

Dari hasil pengujian menyatakan bahwa terdapat pengaruh signifikan yang positif secara bersamaan antara variabel kepemimpinan transformasional dengan employee engagement terhadap kinerja karyawan. Hal tersebut sesuai dengan kondisi di lapangan dimana pemimpin yang selalu memberikan semangat dan motivasi bagi para karyawannya sehingga membuat setiap karyawannya menjadi antusias dan bekerja dengan sungguh-sungguh, yang tentunya dapat meningkatkan kinerja karyawan.

Dijelaskan melalui penelitian milik Putri \& Soedarsono (2017) yang berkaitan dengan penelitian ini dan menyatakan terdapat pengaruh antara peningkatan Kinerja Karyawan Direktorat Solution Operation Telkomsigma dengan variabel Employee Engagement dan Kepemimpinan Transformasional. Menurut Subhi \& Yuniati (2014) kinerja karyawan yaitu di dalam suatu periode tertentu melakukan suatu kegiatan dan pekerjaan dan menghasilkan suatu catatan hasil (output). Menurut Prastyo (2014) kinerja merupakan seberapa banyak organisasi mendapatkan kotribusi dari karyawannya melalui sesuatu yang dilakukan ataupun tidak dilakukan. Kinerja juga dipakai untuk menentukan pemberian kompensasi yang pantas bagi pekerjaan tersebut dengan mengklasifikasikan melalui perbandingan pekerjaan-pekerjaan tersebut. Kinerja selama periode tertentu tersebut, hasil kerja seorang karyawan pada dasarnya akan dibandingkan melalui kemungkinan, contohnya melalui sasaran atau target, standar, maupun kinerja yang sudah disepakati secara bersama dan kinerja yang sudah ditentukan hasilnya.

\section{KESIMPULAN}

Melalui dilakukannya pembahasan, pengolahan data, serta hasil analisis, dapat diartikan bahwa kepemimpinan transformasional mempunyai pengaruh yang positif dan signifikan terhadap kinerja karyawan pada PT. Taspen (Persero) Kantor Cabang Utama Surabaya. Employee engagement mempunyai pengaruh positif dan signifikan terhadap kinerja karyawan pada PT. Taspen (Persero) Kantor Cabang Utama Surabaya. Adanya kinerja karyawan pada PT. Taspen (Persero) Kantor Cabang Utama Surabaya memiliki hubungan yang signifikan dengan employee engagement dan kepemimpinan transformasional.

Untuk meningkatkan kinerja karyawan pada PT. Taspen (Persero) Kantor Cabang Utama Surabaya baiknya memperhatikan kepemimpinan transformasional. Tujuan perusahaan dapat dicapai dengan diperlukannya sebuah kepemimpinan, yaitu cara seorang pemimpin untuk mengatur, mengarahkan, serta mendorong seluruh unsur yang ada pada perusahaan, sehingga terciptanya suatu kinerja dari karyawan dan tercapainya hasil kerja sehingga tujuan perusahaan dapat terwujud. Karyawan dengan kinerja yang baik juga merupakan kontribusi besar dalam tercapainya tujuan perusahaan. Oleh karena itu, sebaiknya karyawan lebih loyal pada perusahaan dengan contoh datang tepat waktu sehingga dengan begitu jam kerja bisa lebih dimaksimalkan dan hasil output menjadi lebih baik, sehingga visi, misi, dan tujuan perusahaan tercapai. Penelitian selanjutnya dapat menambahkan variabel motivasi.

\section{DAFTAR PUSTAKA.}

Andrew, O. C. \& Sofian, S. (2012) 'Individual Factors and Work Outcomes of Employee Engagement', Procedia - Social and Behavioral Sciences. Elsevier B.V., 40, pp. 498-508. doi: 10.1016/j.sbspro.2012.03.222.

Azoury, A., Daou, L. \& Sleiaty, F. (2013) 'Employee engagement in family and non-family firms', International Strategic Management Review. Holy Spirit University of Kaslik, 1(1-2), pp. 1129. doi: 10.1016/j.ism.2013.08.002.

Bai, Y., Lin, L. \& Li, P. P. (2016) 'How to enable employee creativity in a team context: A cross- 
level mediating process of transformational leadership', Journal of Business Research. Elsevier Inc., 69(9), pp. 3240-3250. doi: 10.1016/j.jbusres.2016.02.025.

Bakhtiar. (2019). Kategori kepemimpinan transformational. Jurnal Ilmiah Prodi Pendidikan Agama Islam, 11(1).

Bakti, A. S. (2016). Pengaruh Budaya Organisasi dan Employee Engagement Terhadap Kinerja Karyawan Civil Society Organization PKBI Pusat The Impact of Organizational Culture and Employee Engagement On Employee Work Performance Civil Society Organization IPPA HQ. E-Proceeding Of Management, 3(3), 3088-3095.

Barling, J., Akers, A. \& Beiko, D. (2018) 'The impact of positive and negative intraoperative surgeons' leadership behaviors on surgical team performance', American Journal of Surgery. Elsevier Inc., 215(1), pp. 14-18. doi: 10.1016/j.amjsurg.2017.07.006.

Bedarkar, M. \& Pandita, D. (2014) 'A Study on the Drivers of Employee Engagement Impacting Employee Performance', Procedia - Social and Behavioral Sciences. Elsevier B.V., 133, pp. 106-115. doi: 10.1016/j.sbspro.2014.04.174.

Cavazotte, F., Moreno, V. \& Hickmann, M. (2012) 'Effects of leader intelligence, personality and emotional intelligence on transformational leadership and managerial performance', Leadership Quarterly. Elsevier Inc., 23(3), pp. 443-455. doi: 10.1016/j.leaqua.2011.10.003.

Çekmecelioğlu, H. G. \& Özbağ, G. K. (2016) 'Leadership and Creativity: The Impact of Transformational Leadership on Individual Creativity', Procedia - Social and Behavioral Sciences. Elsevier B.V., 235(October), pp. 243-249. doi: 10.1016/j.sbspro.2016.11.020.

Deinert, A. et al. (2015) 'Transformational leadership sub-dimensions and their link to leaders' personality and performance', Leadership Quarterly. Elsevier Inc., 26(6), pp. 1095-1120. doi: 10.1016/j.leaqua.2015.08.001.

Ghozali, Imam. (2013). Aplikasi Analisis Multivariate dengan Program IBM SPSS 21. Semarang: Badan Penerbit UNDIP

Ghozali, Imam \& Ratmono, Dwi. (2013). Analisis Multivariat dan Ekonometrika: Teori, Konsep, dan Aplikasi dengan EViews 8. Semarang: Badan Penerbit Universitas Diponegoro

Giovanni, J. (2018). Pengaruh Gaya Kepemimpinan Transformasional Terhadap Kinerja dengan Work Engagement sebagai Variabel Pemediasi (Studi Eksplorasi pada Karyawan Usia Muda di Kota Pontianak). Integra, 8(1). https://doi.org/10.35697/jrbi.v2i1.64.

Gruman, J. A. \& Saks, A. M. (2011) 'Performance management and employee engagement', Human Resource Management Review. Elsevier Inc., 21(2), pp. 123-136. doi: 10.1016/j.hrmr.2010.09.004.

Hanaysha, J. (2016) 'Testing the Effects of Employee Engagement, Work Environment, and Organizational Learning on Organizational Commitment', Procedia - Social and Behavioral Sciences. The Author(s), 229, pp. 289-297. doi: 10.1016/j.sbspro.2016.07.139.

Handoyo, A. W., \& Setiawan, R. (2017). Pengaruh Employee Engagement Terhadap Kinerja Karyawan Pada PT. Tirta Rejeki Dewata. Agora, 5(1).

Hayward, Brett Anthony. (2005). Relationship between employee performance, leadership and emotional intelligence in a south african parastatal organization. Thesis: Rhodes University 
Pramita Trisnaning Cahyandani. Pengaruh Kepemimpinan Transformasional dan Employee Engagement terhadap Kinerja Karyawan PT Taspen (Persero) Kantor Cabang Utama Surabaya

J., A. (2014) 'Determinants of employee engagement and their impact on employee performance', International Journal of Productivity and Performance Management, 63(3), pp. 308-323. doi: 10.1108/IJPPM-01-2013-0008.

Jun, S. Y. (2017). The Mediating Effect of Social Capital on the Relationship Between Public Health Managers' Transformational Leadership and Public Health Nurses' Organizational Empowerment in Korea Public Health. Asian Nursing Research, 11(4), 246-252. https://doi.org/10.1016/j.anr.2017.08.006.

Mahendra, K., \& Mujiati, N. (2015). Pengaruh Kepemimpinan Transformasional, Disiplin Kerja, Dan Burnout Pada Kinerja Karyawan Arma Museum and Resort. E-Jurnal Manajemen Universitas Udayana, 4(10), 255182.

Markos, S. \& Sridevi, M. (2010) 'Employee Engagement: The key to improving performance', International Journal of Business and Management, 5(12), pp. 89-96.

McColl-Kennedy, Janet; Anderson, R. (2002) 'Impact of leadership style and emotions on subordinate performance.pdf', The Leadership Quarterly, 13, pp. 545-559.

Nair, M. S. \& Salleh, R. (2015) 'Linking Performance Appraisal Justice, Trust, and Employee Engagement: A Conceptual Framework', Procedia - Social and Behavioral Sciences, 211, pp. 1155-1162. doi: 10.1016/j.sbspro.2015.11.154.

Nguyen, T. T. et al. (2017) 'Effect of transformational-leadership style and management control system on managerial performance', Journal of Business Research. Elsevier Inc., 70, pp. 202213. doi: 10.1016/j.jbusres.2016.08.018.

Prastyo, D. E. (2014). Pengaruh Gaya Kepemimpinan Transformasional terhadap Kinerja Karyawan melalui Kualitas Hubungan. Jurnal Ilmu Manajemen, 2(4).

Purba, C. B., \& Gunawan, P. N. (2018). The Influence of Work Motivation, Organizational Culture and Career Development on Employee Performance in PT. Titis Sampurna Inspection. Saudi Journal of Business and Management Studies (SJBMS), 3(6), 629-640. https://doi.org/10.21276/sjbms.2018.3.6.4.

Putri, M. D., \& Soedarsono, D. K. (2017). Pengaruh Kepemimpinan Transformasional Dan Employee Engagement Terhadap Kinerja Karyawan Direktorat Solution Operation Telkomsigma. EProceeding of Management :, 4(3), 2541-2546.

Putri, S. N. A., \& Dadang, I. (2016). Pengaruh Gaya Kepemimpinan Transformasional Terhadap Kinerja Karyawan ( Studi Kasus Pada Pt . Bank Rakyat Indonesia ( Persero ) Tbk Kantor Cabang Ngawi Jawa Timur ) the Impact of Transformational Leadership on Employees Performance ( Case Study in PT . BA. E-Proceeding Of Management, 3(2), 1086-1095.

Ramadhan, N., \& Sembiring, J. (2014). Pengaruh Employee Engagement Di Human Capital Center. Jurnal Manajemen Indonesia, 14, 47-58.

Samad, S. (2012) 'The Influence of Innovation and Transformational Leadership on Organizational Performance', Procedia - Social and Behavioral Sciences. Elsevier B.V., 57, pp. 486-493. doi: 10.1016/j.sbspro.2012.09.1215.

Sattar, T., Ahmad, K., \& Hassan, S. M. (2015). Role of Human Resource Practices in Employee Performance and Job Satisfaction With Mediating Effect of Employee Engagement. Pakistan Economic and Social Review, 53(1), 81-96. 
Semuel, H., Siagian, H. \& Octavia, S. (2017) 'The Effect of Leadership and Innovation on Differentiation Strategy and Company Performance', Procedia - Social and Behavioral Sciences. The Author(s), 237(June 2016), pp. 1152-1159. doi: 10.1016/j.sbspro.2017.02.171.

Subhi, E. R., \& Yuniati, T. (2014). Pengaruh Kepemimpinan Transformasional Terhadap Kinerja Karyawan Dengan Penghargaan Sebagai Variabel Moderating. Jurnal Ilmu \& Riset Manajemen, 3(2). https://doi.org/10.24843/eeb.2017.v06.i07.p06.

Sugiono, E., \& Rachmawati, W. (2019). Pengaruh Gaya Kepemimpinan Transformasional, Budaya Organisasi dan Motivasi Ekstrinsik Terhadap Kinerja Karyawan PT Semen Padang, Jakarta Selatan. Jurnal Ilmu Manajemen Oikonomia, 13(2), 37-48.

Sugiyono. (2010). Metode Penelitian Pendidikan Pendekatan Kuantitatif, kualitatif, dan R\&D. Bandung: Alfabeta

Sulastri, E. S. G. dan T. (2017). Pengaruh Budaya Organisasi , Motivasi , Dan Kepuasan Kerja Terhadap Kinerja Karyawan PT . PLN ( Persero ) Wilayah Kalimantan Selatan dan Kalimantan. Jurnal Bisnis Dan Pembangunan, 6(1).

Urban, W. (2017) 'System of Amoebas as a Remedy for Employee Engagement Deficits - A Conceptual Deliberation', Procedia Engineering. The Author(s), 182, pp. 725-731. doi: 10.1016/j.proeng.2017.03.188.

Yammarino, F. J., Spangler, W. D. \& Bass, B. M. (1993) 'Transformational Leadership and Performance: A Longitudinal Investigation', Leadership Quarterly, 4(1), pp. 81-102. doi: 10.1016/1048-9843(93)90005-E.

Yıldız, S., Baştürk, F. \& Boz, İ. T. (2014) 'The Effect of Leadership and Innovativeness on Business Performance', Procedia - Social and Behavioral Sciences, 150, pp. 785-793. doi: 10.1016/j.sbspro.2014.09.064.

Zehir, C., Sehitoglu, Y. \& Erdogan, E. (2012) 'The Effect of Leadership and Supervisory Commitment to Organizational Performance', Procedia - Social and Behavioral Sciences, 58, pp. 207-216. doi: 10.1016/j.sbspro.2012.09.994. 